\title{
Preservative-free tafluprost in the treatment of naive patients with glaucoma and ocular hypertension
}

This article was published in the following Dove Press journal:

Clinical Ophthalmology

15 May 2013

Number of times this article has been viewed

\author{
Ines Lanzl' \\ Thomas Hamacher ${ }^{2}$ \\ Klaus Rosbach ${ }^{3}$ \\ Mohammed Osman Ramez ${ }^{4}$ \\ Robert Rothe ${ }^{5}$ \\ Eva Růžičkováb \\ Marta Karhanová ${ }^{7}$ \\ Friedemann Kimmich ${ }^{8}$ \\ 'Private practice, Prien, Germany; \\ ${ }^{2}$ Private practice, Starnberg, Germany; \\ ${ }^{3}$ Private practice, Mainz, Germany; \\ ${ }^{4}$ Private practice, Buxtehude, \\ Germany; ${ }^{5}$ Private practice, Minden, \\ Germany; ${ }^{6}$ General Faculty Hospital, \\ Praha Czech Republic; ${ }^{7}$ Faculty \\ Hospital Olomouc, Czech Republic; \\ ${ }^{8}$ eyecons, Pfinztal, Germany
}

Correspondence: Friedemann Kimmich Eyecons, Woeschbacherstr 37,

D-76327 Pfinztal, Germany

$\mathrm{Tel}+4972$ I 4647234 I

Fax +49 72I 46472349

Email f.kimmich@eyecons.de
Purpose: The study reported here investigated the efficacy, tolerability, and safety of the preservative-free prostaglandin analog tafluprost $0.0015 \%$ in treatment-naive patients.

Patients and methods: Data were collected in two non-interventional, prospective, multicenter, observational, open-label studies of identical design that were conducted in Germany and the Czech Republic. All subjects received preservative-free tafluprost $0.0015 \%$ once daily. Intraocular pressure (IOP) levels were recorded for each eye at untreated baseline and 3 months after initiation of medical treatment. The primary outcome was change in mean IOP from baseline to month 3. In the primary open-angle glaucoma (POAG) and ocular hypertension $(\mathrm{OH})$ patient subgroups, analyses were stratified by the level of baseline IOP: $\geq 20$ to $23 \mathrm{mmHg}$ versus $\geq 24 \mathrm{mmHg}$. In addition, responder rates and the achievement of pre-specified IOP levels at month 3 were evaluated. Local tolerance of preservative-free tafluprost was evaluated by the patients at final visit. Overall satisfaction with the medical treatment was evaluated by both patients and physicians. All adverse events were recorded.

Results: A total of 579 treatment-naive patients with POAG $(n=349)$, OH $(n=105)$, normal tension glaucoma $(n=71)$, exfoliative glaucoma $(n=27)$, or other glaucomas $(n=27)$ were included in this observational study. Mean IOP level at baseline for all patients was $23.6 \pm 4.0 \mathrm{mmHg}$. Mean IOP at month 3 was $16.8 \pm 2.9 \mathrm{mmHg}(-28.8 \%$ vs baseline $)$. At month 3 , significant reductions in mean IOP $(P<0.001)$ were seen in all patients and all subgroups. Preservative-free tafluprost lowered mean IOP significantly in patients with POAG and OH with IOP levels $\geq 20$ to $23 \mathrm{mmHg}$ from $21.9 \pm 1.1 \mathrm{mmHg}$ at baseline to $16.5 \pm 2.2 \mathrm{mmHg}$, and in the subgroup with IOP levels $\geq 24 \mathrm{mmHg}$ from $26.2 \pm 2.4 \mathrm{mmHg}$ to $17.9 \pm 2.4 \mathrm{mmHg}$. In the subgroups of patients with POAG and $\mathrm{OH}$, an IOP response $\geq 20 \%$, $\geq 30 \%$, and $\geq 40 \%$ was achieved by $83.4 \%$, $44.1 \%$, and $12.8 \%$, respectively. Overall, patients with higher baseline IOP values showed a better response than patients with lower baseline IOP levels. Preservative-free tafluprost was well tolerated and safe. After 3 months, $97.9 \%$ of all patients remained on therapy.

Conclusion: In this real-world observational study, treatment with once-daily preservative-free tafluprost proved efficacious, well tolerated, and safe in treatment-naive patients.

Keywords: intraocular pressure, prostaglandin analogs, responders, first-line treatment, preservatives, local tolerability

\section{Introduction}

Lowering intraocular pressure (IOP) using anti-glaucoma medications is considered the first-line effective treatment for glaucoma. ${ }^{1-5}$ Worldwide, prostaglandin analogs (PGAs) have become the major therapeutic class for the medical treatment of glaucoma because of their efficacy and generally well-tolerated systemic safety profile. ${ }^{6}$ Tafluprost (marketed as Taflotan, Tapros, and Saflutan and manufactured by Santen 
Oy, Tampere, Finland) is highly selective for the prostanoid prostaglandin F receptor. ${ }^{7-9}$ PGAs including tafluprost have a strong, sustained, and stable IOP-lowering effect with few systemic side effects. In clinical studies, preservative-free tafluprost lowered IOP effectively and was generally well tolerated. ${ }^{10-13}$ Further, among all widely used PGAs, tafluprost has been the first preparation to be available in a preservativefree formulation.

Benzalkonium chloride (BAK), which is widely used in glaucoma preparations as a preservative, is pro-apoptotic, pro-inflammatory, causes damage to the tear film by disrupting the lipid-layer, and has a negative impact on the number of conjunctival goblet cells. ${ }^{14-18}$ Other clinical studies have demonstrated major differences with respect to subjective symptoms, local tolerability, and objective clinical signs after the use of glaucoma medications containing preservatives and those that are preservative free. ${ }^{19-21}$ These subjective symptoms and clinical signs may have a negative impact on adherence and persistence of glaucoma patients. ${ }^{22,23}$ It should also be considered that there is a high prevalence of ocular surface disease in patients treated for glaucoma and ocular hypertension $(\mathrm{OH}) \cdot{ }^{24-26}$ Finally, the long-term treatment of glaucoma patients with eye drops containing preservatives may have a negative impact on the outcome of filtration sugery. ${ }^{15,27}$

The purpose of this study was to assess the efficacy, tolerability, and safety of preservative-free tafluprost in treatment-naive patients in a routine clinical setting. Prospective, randomized, double-masked clinical trials have provided strong evidence of the efficacy and safety of preservativefree tafluprost, ${ }^{10-13}$ however, they may not completely reflect the conditions found in routine clinical settings due to their restrictive design and inclusion and exclusion criteria. In these clinical trials, usually both treatment-naive patients and those who had had prior medical treatment were included. It remains of interest to prospectively assess the efficacy, tolerability, and safety of preservative-free tafluprost used in monotherapy in a large cohort of treatment-naive patients with different diagnoses and a broad range of baseline IOP levels.

\section{Materials and methods Study design}

This was a prospective, noninterventional, observational, open-label, nonrandomized, multicenter study conducted between July 2009 and March 2011 in Germany and the Czech Republic. A total of 266 centers in Germany and 65 centers in the Czech Republic participated, providing data on 579 treatment-naive patients. The initiation of medical treatment was based on the decision of the physician only. Laws of both countries do not require informed consent for this type of noninterventional observational study.

Treatment-naive patients with glaucoma or $\mathrm{OH}$ were followed for 3 months after initiation of medical therapy with the preservative-free formulation of tafluprost $0.0015 \%$ once daily. The primary objective of this study was to evaluate the change in mean IOP between baseline and final visit. The secondary objective was to determine the change in IOP in different subgroups of treatment-naive patients (primary open-angle glaucoma [POAG], $\mathrm{OH}$, normal tension glaucoma [NTG], exfoliative glaucoma [PEX], and other glaucomas [ie, secondary glaucoma, pigment dispersion, glaucoma with narrow angle component, or not specified]). Further, we evaluated the impact of baseline IOP levels on the IOPlowering effect of preservative-free tafluprost $0.0015 \%$ in patients with POAG and $\mathrm{OH}$. For this analysis, patients with POAG and $\mathrm{OH}$ were stratified by baseline IOP levels ( $\geq 20$ to $23 \mathrm{mmHg}$ and $\geq 24 \mathrm{mmHg}$ ). The cut off level of $24 \mathrm{mmHg}$ was thought to be clinically relevant to roughly distinguish between patients with high versus moderately elevated IOP levels. Tolerability of preservative-free tafluprost and overall satisfaction with preservative-free tafluprost was evaluated at month 3. Adverse events and terminations of medical treatment were recorded.

\section{Patients}

The study included patients with different types of unilateral or bilateral glaucoma (POAG, NTG, PEX, and other glaucomas) and $\mathrm{OH}$ who required initiation of medical hypotensive treatment and who had never been treated for $\mathrm{OH}$ or glaucoma. The initiation of medical treatment was based on the decision of the physician only. Patients with contraindications and known sensitivities to any component of preservative-free tafluprost were excluded from participation according to the summary of product characteristics for preservative-free tafluprost. ${ }^{28}$

\section{Treatment and assessments}

Using standardized data collection forms, investigators provided anonymous patient data. As already indicated, initiation of medical treatment with preservative-free tafluprost was at the physician's discretion. Due to the observational character of the study, no instructions were made to the study participants concerning the time of IOP measurements during the day and when to administer the medication during the day (evening or morning dose). Demographic information 
collected included age, sex, and type of glaucoma. IOP readings were taken at untreated baseline and at the patient's final visit, 3 months after the initiation of medical therapy, using Goldman applanation tonometry in each eye with the patient in a sitting position at the slit lamp. Glaucomatous damage was identified by ophthalmoscopy, automatic perimetry, and/or optic nerve head/fundus imaging techniques. At month 3, subjects were asked to evaluate the tolerability of preservative-free tafluprost referring to a five-point scale ("very good," "good," "satisfactory," "less satisfactory," and "not acceptable"). Overall patient and doctor satisfaction with the medication was evaluated using a four-point scale ("very satisfied," "satisfied," "less satisfied," and "not satisfied"). All adverse events reported by patients and/or observed by physicians and all terminations of medical treatment were recorded.

\section{Statistical analysis}

Efficacy analyses used only IOP measurements of one study eye per subject. If both eyes of a subject were eligible, the eye with the higher IOP at baseline was considered the study eye. If the baseline IOP was the same in both eyes, the right eye was considered the study eye. Paired $t$-tests were conducted to compare mean IOP values at baseline with IOP values 3 months after initiation of treatment with tafluprost $0.0015 \%$. The significance in percentages of patients achieving pre-specified percentage IOP reductions and target IOP levels between the POAG and $\mathrm{OH}$ subgroups (stratified by baseline IOP $\geq 20$ to $23 \mathrm{mmHg}$ and $\geq 24 \mathrm{mmHg}$ ) was assessed using chi-square tests. The two-sided significance level was set at 0.05 .

\section{Results}

\section{Patient demographics}

In total, 579 treatment-naive patients were included in this observational study between July 2009 and March 2011. Most patients were female $(n=327 ; 56.5 \%)$ and the mean age was 58.1 years. POAG was the most common diagnosis ( $\mathrm{n}=349 ; 60.3 \%)$, followed by $\mathrm{OH}(\mathrm{n}=105 ; 18.1 \%)$, NTG $(n=71 ; 12.3 \%)$, PEX $(n=27 ; 4.7 \%)$, and other glaucomas $(n=27 ; 4.7 \%)$ (Table 1$)$.

\section{Effect on mean IOP}

Overall, mean IOP ( \pm standard deviation [SD]) was $23.6 \pm 4.0 \mathrm{mmHg}$ at baseline. Three months after initiation of medical therapy, IOP decreased significantly to $16.8 \pm 2.9 \mathrm{mmHg}$. This IOP decrease is equivalent to $6.8 \mathrm{mmHg}$, or $28.8 \%$, versus untreated baseline. A significant
Table I Patient demographics

\begin{tabular}{ll}
\hline Subjects $(\mathrm{n})$ & 579 \\
Age, years (mean [range]) & 58.1 (I6-93) \\
$\quad$ Standard deviation & 13.2 \\
Sex, $\mathrm{n}$ (male/female/no data) & $247 / 327 / 5$ \\
Diagnoses, $\mathrm{n}(\%)$ & \\
Ocular hypertension & $105(18.1)$ \\
Primary open-angle glaucoma & $349(60.3)$ \\
Normal tension glaucoma & $71(12.3)$ \\
Exfoliative glaucoma & $27(4.7)$ \\
Other glaucomas* & $27(4.7)$ \\
\hline
\end{tabular}

Notes: *Other glaucomas include secondary glaucoma $(n=12)$, pigment dispersion $(n=2)$, glaucoma with narrow angle component $(n=3)$, and not specified $(n=10)$.

decrease in mean IOP was also achieved for all different subgroups by diagnosis: in patients with POAG $(n=349)$, mean IOP $( \pm \mathrm{SD})$ was significantly lowered from $24.6 \pm 2.9 \mathrm{mmHg}$ at baseline to $17.3 \pm 2.4 \mathrm{mmHg}$ at final visit; in patients with $\mathrm{OH}(\mathrm{n}=105)$, from $24.4 \pm 2.6 \mathrm{mmHg}$ to $17.5 \pm 2.4 \mathrm{mmHg}$; in patients with NTG $(\mathrm{n}=71)$, from $16.6 \pm 1.9 \mathrm{mmHg}$ to $13.3 \pm 2.4 \mathrm{mmHg}$; in patients with $\operatorname{PEX}(\mathrm{n}=27)$, from $25.8 \pm 3.5 \mathrm{mmHg}$ to $17.5 \pm 2.4 \mathrm{mmHg}$; and in patients with other glaucomas $(\mathrm{n}=27)$, from $23.7 \pm 5.4 \mathrm{mmHg}$ to $16.7 \pm 4.4 \mathrm{mmHg}$. Further details are shown in Table 2 .

\section{Percentage IOP reduction and achievement of target IOP levels}

In patients with POAG or $\mathrm{OH}$, an IOP reduction $\geq 20 \%$ versus untreated baseline IOP levels was achieved by $83.4 \%$ of patients and an IOP reduction $\geq 30 \%$ and $\geq 40 \%$ by $44.1 \%$ and $12.8 \%$ of patients, respectively. In the subgroup of patients with PEX, 92.6\% achieved an IOP reduction $\geq 20 \%$ and $48.1 \%$ and $22.2 \%$ of patients achieved an IOP reduction $\geq 30 \%$ and $\geq 40 \%$, respectively. Percentage IOP reduction was lower in the patient subgroup with NTG: $53.5 \%$ of patients achieved an IOP reduction $\geq 20 \%$ versus untreated baseline, while $21.1 \%$ and $2.8 \%$ achieved an IOP reduction $\geq 30 \%$ and $\geq 40 \%$, respectively (Figure 1 ).

The target IOP level of $\leq 18 \mathrm{mmHg}$ was achieved by $61.7 \%$ of patients with POAG and $\mathrm{OH}$ and by $98.6 \%, 66.7 \%$, and $66.7 \%$ of patients with NTG, PEX, and other glaucomas, respectively. A low target IOP level of $\leq 14 \mathrm{mmHg}$ was achieved by $6.7 \%, 69.0 \%, 7.4 \%$, and $29.6 \%$ of patients with POAG/OH, NTG, PEX, and other glaucomas, respectively (Figure 2).

\section{Reduction in IOP in patients with POAG and $\mathrm{OH}$ stratified by baseline IOP levels}

At month 3, mean IOP levels decreased from baseline by $5.4 \pm 2.2 \mathrm{mmHg}(-24.7 \%)$ in the subgroup of patients 
Table 2 Change in mean intraocular pressure (IOP) from baseline to final visit 12 weeks after initiation of medical therapy with preservative-free tafluprost

\begin{tabular}{|c|c|c|c|c|c|c|c|}
\hline Diagnosis & $\mathbf{n}$ & $\begin{array}{l}\text { Eyes, n } \\
\text { (RE/LE) }\end{array}$ & $\begin{array}{l}\text { Mean IOP at baseline, } \\
\mathrm{mmHg} \pm \mathrm{SD} \\
\text { (range, } \mathrm{mmHg} \text { ) }\end{array}$ & $\begin{array}{l}\text { Mean IOP at final visit, } \\
\mathrm{mmHg} \pm \mathrm{SD} \\
\text { (range, } \mathrm{mmHg} \text { ) }\end{array}$ & $\begin{array}{l}\Delta \text { IOP baseline vs } \\
\text { final visit } \\
(\mathrm{mmHg})\end{array}$ & $\begin{array}{l}\% \text { change in IOP } \\
\text { at baseline vs } \\
\text { final visit }\end{array}$ & $P *$ \\
\hline All patients & 579 & $347 / 232$ & $23.6 \pm 4.0(6-38)$ & $16.8 \pm 2.9(7-27)$ & -6.8 & -28.8 & $<0.001$ \\
\hline POAG & 349 & $207 / 149$ & $24.6 \pm 2.9(19-38)$ & $17.3 \pm 2.4(10-25)$ & -7.3 & -29.7 & $<0.001$ \\
\hline $\mathrm{OH}$ & 105 & $59 / 46$ & $24.4 \pm 2.6(22-38)$ & $17.5 \pm 2.4(12-27)$ & -6.9 & -28.3 & $<0.001$ \\
\hline NTG & 71 & $49 / 22$ & $16.6 \pm 1.9(6-19)$ & $13.3 \pm 2.4(7-19)$ & -3.3 & -19.9 & $<0.001$ \\
\hline PEX & 27 & $16 / 11$ & $25.8 \pm 3.5(19-37)$ & $17.5 \pm 2.4(10-22)$ & -8.3 & -32.2 & $<0.001$ \\
\hline OG & 27 & $16 / 11$ & $23.7 \pm 5.4(10-36)$ & $16.7 \pm 4.4(9-26)$ & -7.0 & -29.5 & $<0.001$ \\
\hline
\end{tabular}

Note: ${ }^{t}$-test for paired samples.

Abbreviations: $\triangle$ IOP, IOP at final visit minus IOP at baseline; LE, left eyes; NTG, normal tension glaucoma; OG, other glaucomas; OH, ocular hypertension; PEX, exfoliative glaucoma; POAG, primary open-angle glaucoma; RE, right eyes; SD, standard deviation.

with baseline IOP levels $\geq 20$ to $23 \mathrm{mmHg}$ and by $8.3 \pm 3.0 \mathrm{mmHg}(-31.7 \%)$ in the subgroup of patients with baseline IOP levels $\geq 24 \mathrm{mmHg}(P<0.0001$ for withingroup comparison) (Table 3 ). Similarly large percentages of patients achieved $\geq 10 \%$ IOP reductions at month 3 compared with untreated baseline in both subgroups: $94.2 \%$ in the $\geq 20$ to $23 \mathrm{mmHg}$ subgroup and $98.6 \%$ in the $\geq 24 \mathrm{mmHg}$ subgroup $(P=0.119)$ (Table 3$)$. A significantly smaller percentage of patients in the $\geq 20$ to $23 \mathrm{mmHg}$ subgroup achieved IOP reductions - $\geq 30 \%$ compared with the $\geq 24 \mathrm{mmHg}$ subgroup (29.7\% vs $52.8 \%$ respectively; $P<0.0001 \%)$. However, significantly smaller percentages of patients in the $\geq 24 \mathrm{mmHg}$ subgroup achieved IOP levels $\leq 21 \mathrm{mmHg}$, $\leq 18 \mathrm{mmHg}$, or $\leq 15 \mathrm{mmHg}$ at month $3(P \leq 0.05$ for IOP levels $\leq 21 \mathrm{mmHg}$ and $P<0.0001$ for IOP levels $\leq 18$ or $\leq 15 \mathrm{mmHg}$ ) (Figure 3).

\section{Local tolerability and satisfaction}

At final visit, 3 months after the initiation of medical treatment, the local tolerability of preservative-free tafluprost was rated as "very good" or "good" by $91.4 \%$ of all treatment-naive patients. Evaluation of local tolerability was comparable in all patient subgroups. Local tolerability of preservative-free tafluprost was rated as "less satisfactory" or "not acceptable" by only a few patients $(1.7 \%$ of all patients; $1.2 \%$ of patients with POAG, $1.0 \%$ of patients with $\mathrm{OH}, 3.7 \%$ of patients with PEX, and $1.4 \%$ of patients with NTG) (Figure 4). Most patients (96.5\%) and physicians

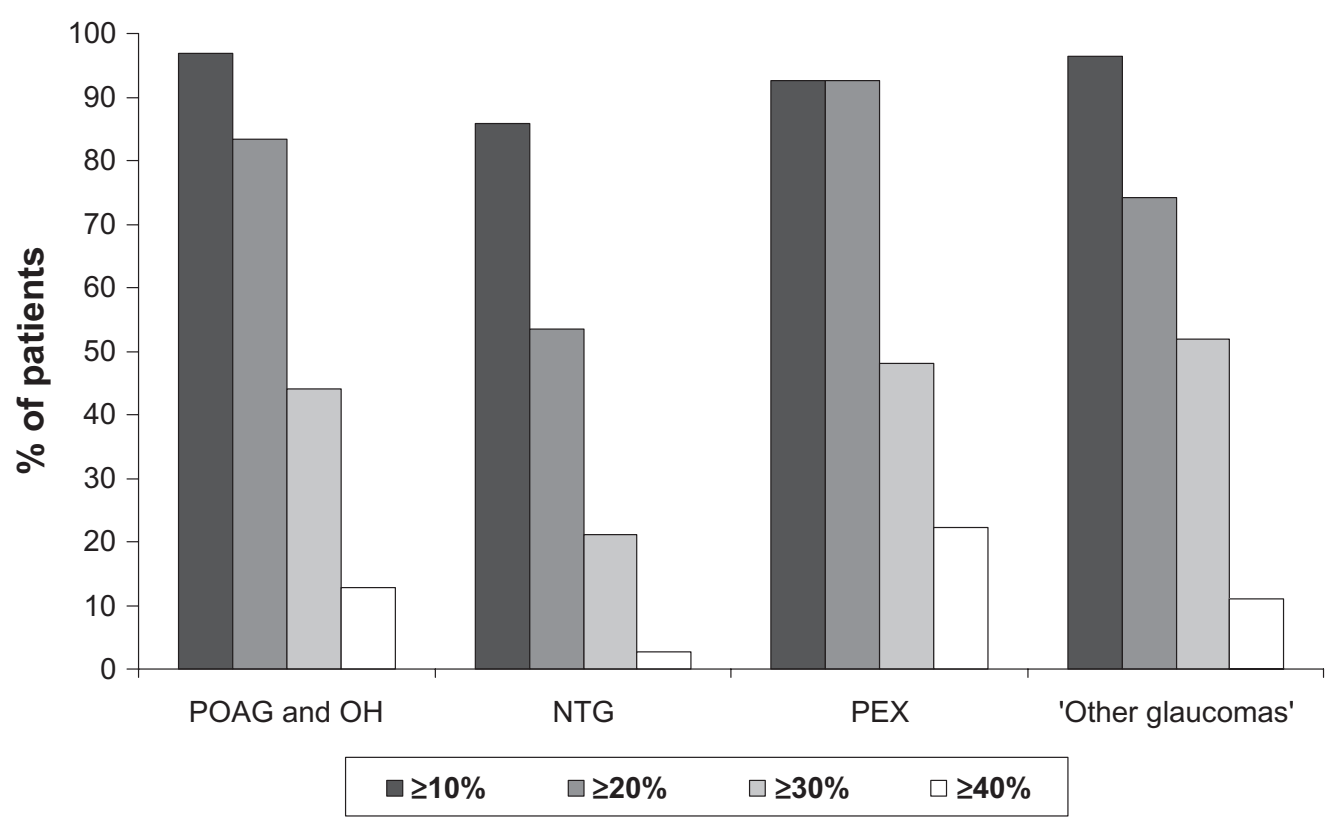

Figure I Percentage intraocular pressure (IOP) reduction at final visit versus untreated baseline for different patient subgroups. Notes: IOP reductions are classified into four categories: $\geq 10 \%, \geq 20 \%, \geq 30 \%$, and $\geq 40 \%$.

Abbreviations: NTG, normal tension glaucoma; OH, ocular hypertension; PEX, exfoliative glaucoma; POAG, primary open-angle glaucoma. 


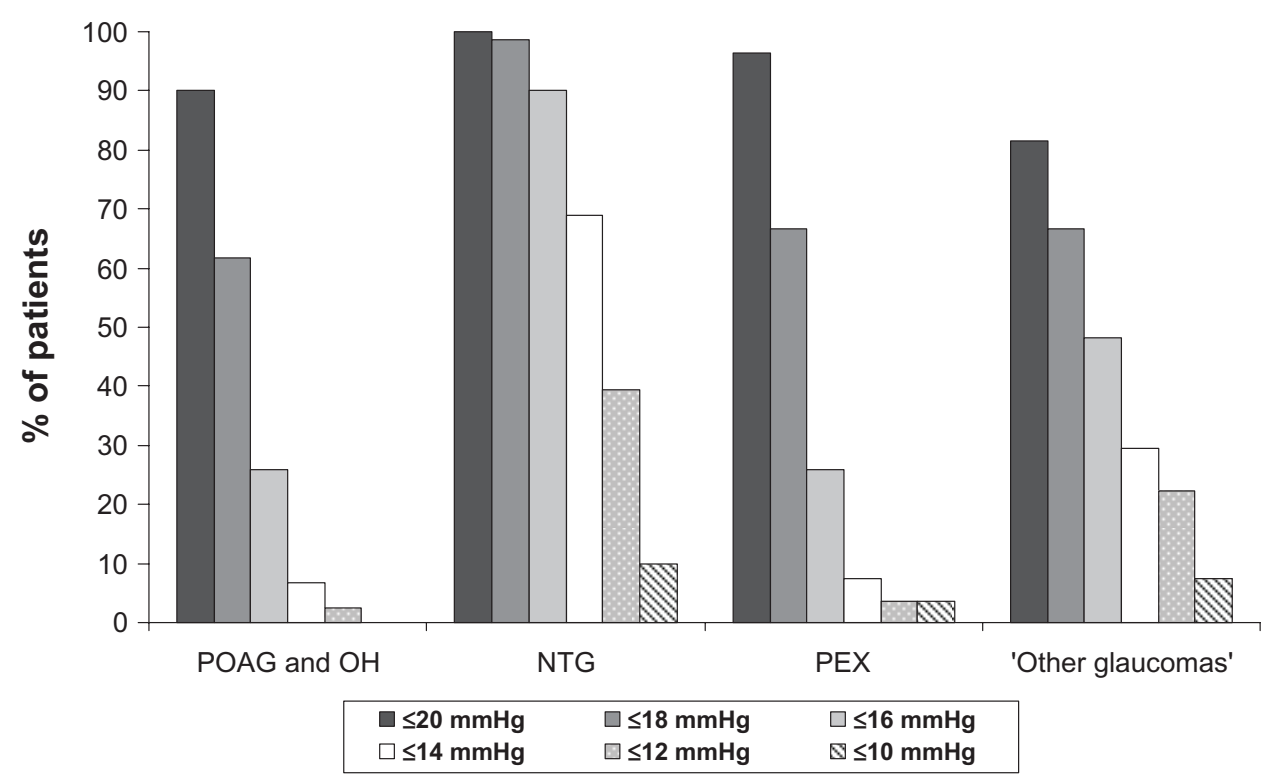

Figure 2 Achievement of specific intraocular pressure levels at final visit versus untreated baseline for different patient subgroups.

Abbreviations: NTG, normal tension glaucoma; OH, ocular hypertension; PEX, exfoliative glaucoma; POAG, primary open-angle glaucoma.

$(95.2 \%)$ were either "very satisfied" or "satisfied" with the medical treatment at final visit.

\section{Safety and terminations of treatment}

Few adverse events were associated with the use of preservative-free tafluprost. A total of 567 patients (97.9\%) completed the study and continued preservative-free tafluprost monotherapy. Four patients $(0.9 \%)$ terminated the treatment due to a lack of efficacy, two patients of their own volition, and one patient each $(0.2 \%)$ in each case due to conjunctival hyperemia, conjunctival headache and increased contrast sensitivity. Further details on adverse events and terminations of treatment are shown in Table 4.

\section{Discussion}

A large body of evidence exists showing that the long-term use of topical drugs containing BAK as a preservative may induce changes to the ocular surface, tear film instability, epithelial apoptosis, conjunctival inflammation, and the loss of goblet cells. ${ }^{14-18}$ Different studies have also confirmed that the prevalence of ocular surface disorders is high in glaucoma patients: in a study by Leung et al, $59 \%$ of patients with open-angle glaucoma or $\mathrm{OH}$ reported dry eye symptoms in at least one eye. ${ }^{24}$ In another study by Erb et al, dry eye syndrome was diagnosed in $52.6 \%$ of glaucoma patients. ${ }^{25}$ In both studies, the occurrence of dry eye syndrome increased with the number of preservative-containing anti-glaucoma drugs used. With respect to local tolerability of glaucoma medications, clinical studies report that a high proportion of glaucoma patients developed subjective symptoms such as burning and stinging, foreign body sensation, dry eye, and irritation of the ocular surface; these subjective symptoms were reported significantly less often in patients receiving preservative-free preparations. ${ }^{19-21}$

Table 3 Intraocular pressure (IOP) \pm standard deviation (SD) in patients with primary open-angle glaucoma and ocular hypertension at baseline and at month 3 after initiation of medical treatment

\begin{tabular}{|c|c|c|}
\hline & $\begin{array}{l}\text { Baseline IOP } \geq \\
20 \text { to } 23 \mathrm{mmHg} \\
(n=172)\end{array}$ & $\begin{array}{l}\text { Baseline IOP } \geq \\
24 \mathrm{mmHg} \\
(\mathrm{n}=282)\end{array}$ \\
\hline $\begin{array}{l}\text { Mean baseline IOP } \\
(\mathrm{mmHg}) \pm \mathrm{SD}\end{array}$ & $21.9 \pm 1.1$ & $26.2 \pm 2.4$ \\
\hline IOP month $3(\mathrm{mmHg}) \pm \mathrm{SD}$ & $16.5 \pm 2.2$ & $17.9 \pm 2.4$ \\
\hline $\begin{array}{l}\text { Change in mean IOP } \\
\text { from baseline to } \\
\text { month } 3(\mathrm{mmHg}) \pm \mathrm{SD}\end{array}$ & $5.4 \pm 2.2$ & $8.3 \pm 3.0$ \\
\hline$p^{*}$ & $<0.0001$ & $<0.0001$ \\
\hline $\begin{array}{l}\% \text { change in IOP from } \\
\text { baseline to month } 3\end{array}$ & 24.7 & 31.7 \\
\hline $\begin{array}{l}\geq 10 \% \text { IOP reduction from } \\
\text { baseline to month } 3, \mathrm{n}(\%)^{\mathrm{a}}\end{array}$ & $162(94.2)$ & $278(98.6)$ \\
\hline $\begin{array}{l}\geq 20 \% \text { IOP reduction from } \\
\text { baseline to month } 3, \mathrm{n}(\%)^{\mathrm{b}}\end{array}$ & $120(69.8)$ & $258(91.5)$ \\
\hline $\begin{array}{l}\geq 30 \% \text { IOP reduction from } \\
\text { baseline to month } 3, n(\%)^{c}\end{array}$ & $51(29.7)$ & $149(52.8)$ \\
\hline $\begin{array}{l}\geq 40 \% \text { IOP reduction from } \\
\text { baseline to month } 3, n(\%)^{d}\end{array}$ & $8(4.7)$ & $50(17.7)$ \\
\hline
\end{tabular}

Notes: ${ }^{*} t$-test for paired samples. ${ }^{a} P=0.119$ for between-group difference; Chisquare test; ${ }^{b} P<0.1$ for between-group difference; Chi-square test; ${ }^{c} P<0.000$ I for between-group difference; Chi-square test; ${ }^{d} P<0.003$ for between-group difference; Chi-square test. 


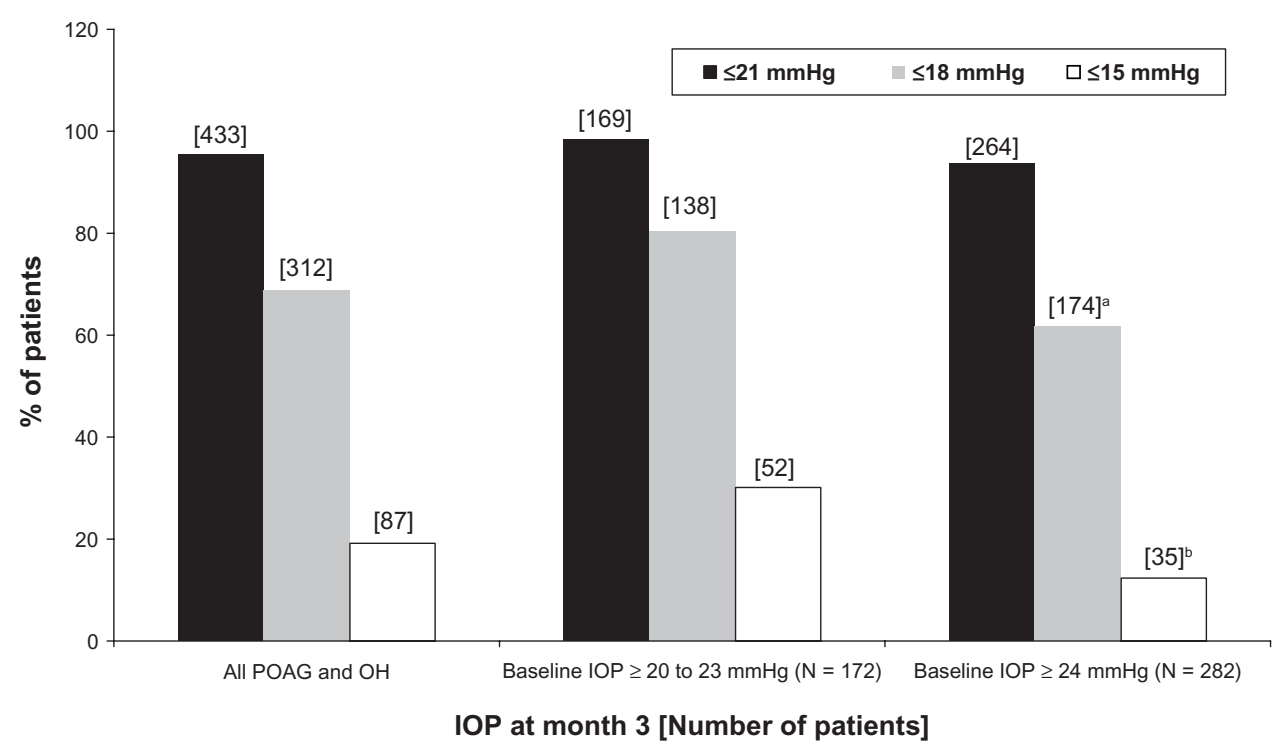

Figure 3 Achievement of specific intraocular pressure (IOP) levels at final visit versus untreated baseline in all patients with primary open-angle glaucoma (POAG) and ocular hypertension $(\mathrm{OH})$ and in the two subgroups stratified by baseline IOP levels at month 3 after initiation of medical treatment.

Notes: ${ }^{a} P \leq 0.05$ for between-group difference: Chi-square test; ${ }^{b} P<0.000$ I for between-group difference: Chi-square test.

All these aspects are of importance when considering the treatment of treatment-naive glaucoma and $\mathrm{OH}$ patients in order to avoid any changes to the ocular surface and tear film induced by exposure to BAK during long-term treatment.

The results of this noninterventional, open-label, multicenter observational study demonstrate that preservative-free tafluprost can achieve good IOP control in treatment-naive patients and that the drug is well tolerated: after initiation of medical treatment with the preservative-free PGA, mean IOP decreased significantly by $6.8 \mathrm{mmHg}(28.8 \%)$ until final visit at month 3 in all patients. Mean IOP also decreased significantly in all subgroups of patients with POAG/OH, NTG, PEX, and other glaucomas: in patients with NTG, mean IOP decreased by $3.3 \mathrm{mmHg}$ from $16.6 \mathrm{mmHg}$ to $13.3 \mathrm{mmHg}$. This is slightly higher than the findings of a randomized, crossover study, in which tafluprost lowered

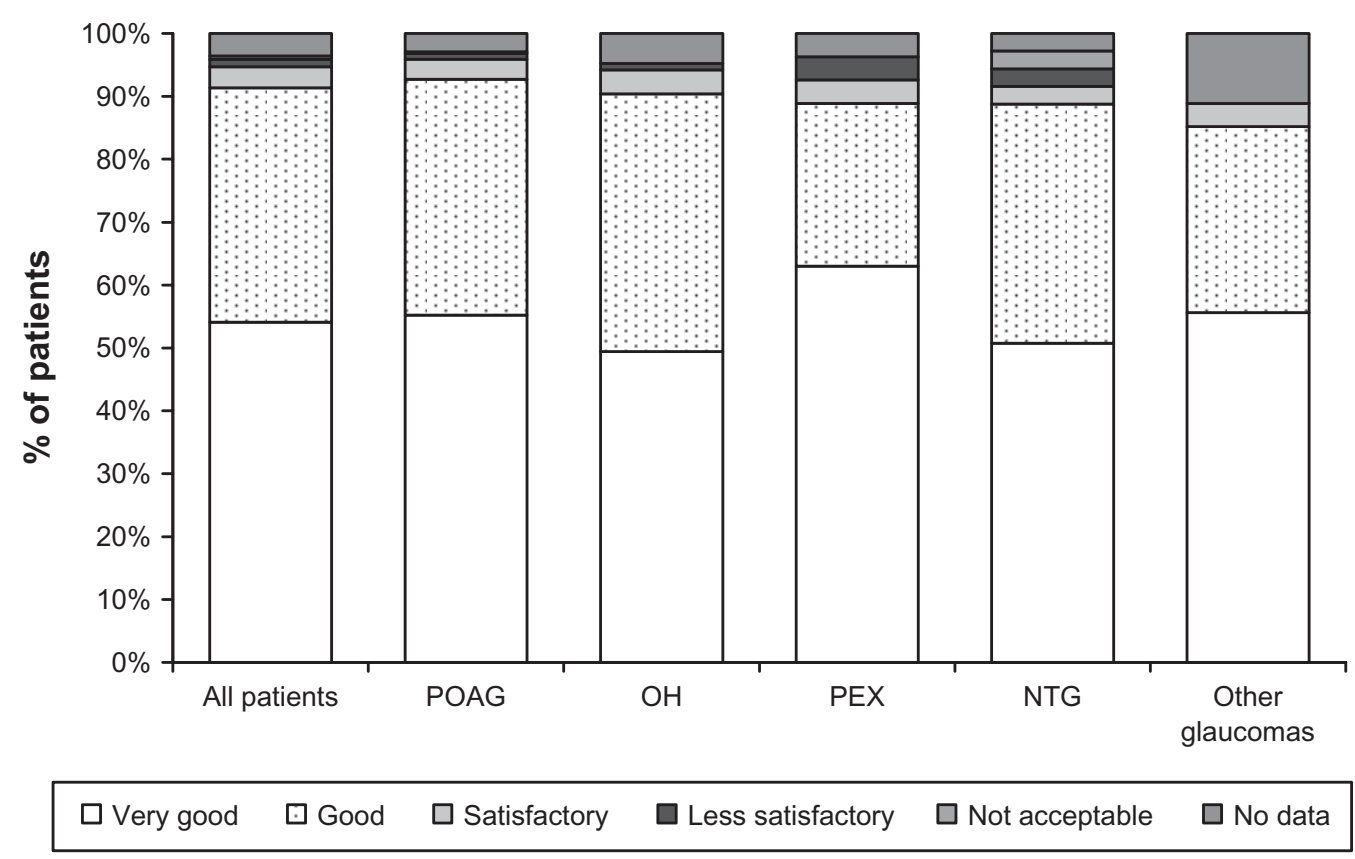

Figure 4 Local tolerability of preservative-free tafluprost at month 3 for all patients and for different patient subgroups.

Abbreviations: NTG, normal tension glaucoma; $\mathrm{OH}$, ocular hypertension; PEX, exfoliative glaucoma; POAG, primary open-angle glaucoma. 
Table 4 Adverse events and terminations of treatment

\begin{tabular}{|c|c|c|c|c|c|}
\hline Adverse event/complaint & Diagnosis & Patients, $\mathbf{n}$ & Patients, \% & Termination, $\mathbf{n}$ & Termination, \% \\
\hline Lack of IOP-lowering & POAG & 4 & 0.7 & 3 & 0.5 \\
\hline \multirow[t]{4}{*}{ efficacy } & $\mathrm{OH}$ & I & 0.2 & 0 & 0.0 \\
\hline & PEX & 2 & 0.3 & 0 & 0.0 \\
\hline & NTG & 1 & 0.2 & I & 0.2 \\
\hline & Other glaucomas & 1 & 0.2 & 0 & 0.0 \\
\hline \multirow[t]{2}{*}{ Conjunctival hyperemia } & $\mathrm{OH}$ & 2 & 0.3 & 1 & 0.2 \\
\hline & POAG & 1 & 0.2 & 0 & 0.0 \\
\hline Hyperemia and eyelid & $\mathrm{OH}$ & 1 & 0.2 & I & 0.2 \\
\hline \multicolumn{6}{|l|}{ hyperpigmentation } \\
\hline Itching & POAG & 1 & 0.2 & I & 0.2 \\
\hline Headache & POAG & 1 & 0.2 & I & 0.2 \\
\hline Increased contrast sensitivity & POAG & 1 & 0.2 & I & 0.2 \\
\hline Patient decision & NTG & 2 & 0.3 & 2 & 0.3 \\
\hline Unknown & POAG & 1 & 0.2 & I & 0.2 \\
\hline Total & & 19 & 3.3 & 12 & 2.1 \\
\hline \multicolumn{4}{|c|}{ Remaining on monotherapy after final visit (month 3) } & 567 & 97.9 \\
\hline \multicolumn{4}{|l|}{ Total } & 579 & 100.0 \\
\hline
\end{tabular}

Abbreviations: NTG, normal tension glaucoma; OH, ocular hypertension; PEX, exfoliative glaucoma; POAG, primary open-angle glaucoma.

IOP by $2.3 \mathrm{mmHg}$ from $15.5 \mathrm{mmHg}$ to $13.2 \mathrm{mmHg}$ after 12 weeks and travoprost by $2.2 \mathrm{mmHg}$ from $15.4 \mathrm{mmHg}$ to $13.2 \mathrm{mmHg} .{ }^{29}$ However, it should be noted that the baseline IOP levels in the present study were higher, which may have had an impact on the IOP decrease.

Ang et al reported a decrease in mean IOP in naive patients with NTG after treatment with latanoprost from 16.9 to $14.1 \mathrm{mmHg}(17 \%) .{ }^{30}$ Another study found a decrease in average IOP of $1.98 \mathrm{mmHg}(16.1 \%)$ in treatment-naive patients with NTG after medical treatment with travoprost $0.004 \%{ }^{31}$ Suh et al reported a decrease in IOP of 2.71 to $3.71 \mathrm{mmHg}$ ( $18.3 \%$ to $25.1 \%$ ) in patients with NTG treated with travoprost over 12 months. ${ }^{32}$ Tsumura et al reported a decrease in mean IOP of $3.9 \mathrm{mmHg}$ in NTG patients from 14.5 to $10.6 \mathrm{mmHg}$ after 12 weeks treatment with bimatoprost; a $20 \%$ decrease from baseline was seen in about half of the subjects. ${ }^{33}$ This is consistent with our finding of a $\geq 20 \%$ IOP reduction in $53.5 \%$ of NTG patients treated with preservative-free tafluprost. In a 3-month study comparing the IOP-lowering efficacy of bimatoprost and latanoprost in patients with NTG, Dirks et al found a reduction in mean IOP of $3.4 \mathrm{mmHg}$ with bimatoprost and $2.3 \mathrm{mmHg}$ with latanoprost. In their study, mean baseline IOP values were $17.2 \mathrm{mmHg}$ in the bimatoprost and $16.2 \mathrm{mmHg}$ in the latanoprost treatment arm. ${ }^{34}$ Two other studies found a decrease in IOP from a baseline IOP level of $13.9 \mathrm{mmHg}$ by $2.5 \mathrm{mmHg}$ and $2.6 \mathrm{mmHg}$ for latanoprost and travoprost, respectively, and $2.6 \mathrm{mmHg}$ for travoprost from a baseline IOP level of $12.9 \mathrm{mmHg} .{ }^{35,36}$

There are few reports on the effects of PGAs in patients with PEX. In a study by Konstas et al, the efficacy and safety of latanoprost and travoprost were compared in PEX patients with IOP values $>24 \mathrm{mmHg}$. After 8 weeks of treatment, mean 24-hour IOP was lowered from $25.1 \pm 2.5 \mathrm{mmHg}$ at baseline to $17.8 \pm 2.1 \mathrm{mmHg}$ on latanoprost $(-7.3 \mathrm{mmHg})$ and from $25.1 \pm 2.5 \mathrm{mmHg}$ at baseline to $17.9 \pm 2.1 \mathrm{mmHg}$ $(-7.2 \mathrm{mmHg})$ on travoprost. ${ }^{37}$ Another study comparing bimatoprost and latanoprost in patients with PEX found a reduction in mean IOP from $26.9 \pm 3.5 \mathrm{mmHg}$ at baseline to $17.6 \pm 3.3 \mathrm{mmHg}(-9.3 \mathrm{mmHg})$ in the bimatoprost treatment arm and to $18.6 \pm 3.6 \mathrm{mmHg}(-8.3 \mathrm{mmHg})$ in the latanoprost treatment arm. ${ }^{38}$ In the present observational study, preservative-free tafluprost lowered the mean IOP in patients with PEX from $25.8 \pm 3.5 \mathrm{mmHg}$ at baseline to $17.5 \pm 2.4 \mathrm{mmHg}(-8.3 \mathrm{mmHg})$ at month 3 , which is in a comparable range with the published data for latanoprost, travoprost, and bimatoprost.

Uveoscleral outflow seems to be reduced in patients with exfoliation syndrome. ${ }^{39}$ This may, at least in part, explain the excellent IOP response of patients with PEX to PGAs, as seen in this study. However, it also should be noted that mean baseline IOP in this patient subgroup was more than $1 \mathrm{mmHg}$ higher than in other patient subgroups. A higher baseline IOP might affect the absolute and percentage IOPlowering efficacy of glaucoma medications, as can be seen in the present study in the POAG and $\mathrm{OH}$ subgroups. As would be expected, absolute and percentage IOP reductions were greater in patients with $\mathrm{POAG}$ and $\mathrm{OH}$ with higher baseline IOP values ( $\geq 24 \mathrm{mmHg}$ ). Several other studies have reported that higher baseline IOP levels are associated with larger IOP reductions. ${ }^{40,41}$ This finding may partly be explained by a 
regression to the mean. However, in the present study, significant IOP responses to preservative-free tafluprost were seen in both subgroups of patients with POAG and $\mathrm{OH}$ stratified by baseline IOP levels: IOP levels $\leq 18 \mathrm{mmHg}$ were achieved by $61.7 \%, 98.6 \%, 66.7 \%$, and $66.7 \%$ of patients with POAG/OH, NTG, PEX, and other glaucomas, respectively. Also, when stratified by untreated IOP levels in patients with POAG or $\mathrm{OH}$, IOP levels $\leq 18 \mathrm{mmHg}$ were achieved by $80.2 \%$ and $61.7 \%$ in the $\geq 20$ to $23 \mathrm{mmHg}$ and $\geq 24 \mathrm{mmHg}$ patient subgroups, respectively. Further, more than $94 \%$ of patients in both subgroups achieved IOP reductions $\geq 10 \%$ at month 3 . These findings are consistent with a meta-analysis of studies with latanoprost in patients with glaucoma and $\mathrm{OH}$ showing IOP reductions $>15 \%$ in $93 \%$ of patients. ${ }^{40}$ Denis et al reported a $\geq 10 \%$ reduction of IOP in $94 \%$ of patients with POAG and $\mathrm{OH}$ treated with latanoprost. ${ }^{41}$

Various studies ${ }^{42-46}$ have reported preservative-free tafluprost to be well tolerated and safe and we found this to be true in our study also. In the present study, only twelve patients $(2.1 \%)$ terminated their medical treatment during the research period. Conjunctival hyperemia occurred in four patients $(0.7 \%)$, which was fewer than in a previous study comparing latanoprost, bimatoprost, and travoprost in treatment-naive patients. In that study, hyperaemia rates of 12.5 and $17.5 \%$ were reported for patients treated with bimatoprost, 4.8 and $7.1 \%$ of patients treated with latanoprost, and 17.5 and $10 \%$ of patient treated with travoprost after 2 and 6 months respectively. ${ }^{47}$ The lower rate of conjunctival hyperemia may be explained by the preservative-free formulation of tafluprost and a lower concentration of the active ingredient tafluprost.

While the present study is limited by its open-label design, the design may better reflect the treatment algorithms of dayto-day practice. Due to its observational nature, no causal relationships were revealed. Further, regression to the mean cannot be ruled out. Further well-controlled clinical studies are necessary to determine which aspects of preservative-free therapy with tafluprost may account for the observed effects.

\section{Conclusion}

In this study, preservative-free tafluprost $0.0015 \%$ was efficacious, well tolerated, and safe in treatment-naive patients. IOP response was generally good in all subgroups of patients and in both subgroups of patients with POAG and $\mathrm{OH}$ stratified by untreated baseline IOP levels; IOP was lowered effectively in all subgroups of patients. IOP reductions in the subgroup of patients with POAG and $\mathrm{OH}$ were smaller in patients with lower baseline IOP ( $\geq 20$ to $23 \mathrm{mmHg}$ ) than in patients with higher baseline IOPs ( $\geq 24 \mathrm{mmHg}$ ). Preservative-free tafluprost was well tolerated; few ocular side effects were noted during the study period. Conjunctival hyperemia was observed in four patients $(0.7 \%)$. Moreover, treatment with preservative-free tafluprost was safe. Few patients terminated therapy due to lack of efficacy (four patients; $0.7 \%$ ) and adverse events (eight patients; 1.4\%). Thus, our data suggest that preservative-free tafluprost may be especially beneficial for treatment-naive patients in order to avoid treatment-related side effects induced by treatments containing preservatives.

\section{Disclosure}

This study was financially supported by Santen Oy, Tampere, Finland. I Lanzl is a speaker for Santen Oy and F Kimmich is a consultant for Santen Oy. Medical writing, data management, and statistical analysis of the present study were done by eyecons (F Kimmich), with financial support from Santen Oy. The authors declare no other conflicts of interest in this work.

\section{References}

1. Heijl A, Leske MC, Bengtsson B, Hyman L, Bengtsson B, Hussein M; Early Manifest Glaucoma Trial Group. Reduction of intraocular pressure and glaucoma progression: results from the Early Manifest Glaucoma Trial. Arch Ophthalmol. 2002;120(10):1268-1279.

2. The Advanced Glaucoma Intervention Study (AGIS): 7. The relationship between control of intraocular pressure and visual field deterioration. The AGIS Investigators. Am J Ophthalmol. 2000;130(4):429-440.

3. Kass MA, Heuer DK, Higginbotham EJ, et al. The Ocular Hypertension Treatment Study: a randomized trial determines that topical ocular hypotensive medication delays or prevents the onset of primary openangle glaucoma. Arch Ophthalmol. 2002;120(6):701-713.

4. The effectiveness of intraocular pressure reduction in the treatment of normal-tension glaucoma. Collaborative Normal-Tension Glaucoma Study Group. Am J Ophthalmol. 1998;126(4):498-505.

5. European Glaucoma Society. Terminology and Guidelines for Glaucoma, 3rd ed. Savona: Dogma; 2008.

6. Bean GW, Camras CB. Commercially available prostaglandin analogs for the reduction of intraocular pressure: similarities and differences. Surv Ophthalmol. 2008;53 Suppl 1:S69-S84.

7. Nakajima T, Matsugi T, Goto W, et al. New fluoroprostaglandin F(2alpha) derivatives with prostanoid FP-receptor agonistic activity as potent ocular-hypotensive agents. Biol Pharm Bull. 2003;26(12):1691-1695.

8. Takagi Y, Nakajima T, Shimazaki A, et al. Pharmacological characteristics of AFP-168 (tafluprost), a new prostanoid FP receptor agonist, as an ocular hypotensive drug. Exp Eye Res. 2004;78(4):767-776.

9. Sutton A, Gouws P, Ropo A. Tafluprost, a new potent prostanoid receptor agonist: a dose-response study on pharmacodynamics and tolerability in healthy volunteers. Int J Clin Pharmacol Ther. 2008;46(8):400-406.

10. Uusitalo H, Pillunat LE, Ropo A; Phase III Study Investigators. Efficacy and safety of tafluprost $0.0015 \%$ versus latanoprost $0.005 \%$ eye drops in open-angle glaucoma and ocular hypertension: 24-month results of a randomized, double-masked phase III study. Acta Ophthalmol. 2010;88(1):12-19.

11. Traverso CE, Ropo A, Papadia M, Uusitalo H. A phase II study on the duration and stability of the intraocular pressure-lowering effect and tolerability of Tafluprost compared with latanoprost. J Ocul Pharmacol Ther. 2010;26(1):97-104. 
12. Kuwayama Y, Komemushi S; Tafluprost Multi-center Study Group. Intraocular pressure lowering effect of $0.0015 \%$ tafluprost as compared to placebo in patients with normal tension glaucoma: randomized, double-blind, multicenter, phase III study. Nihon Ganka Gakkai Zasshi. 2010;114(5):436-443. Japanese.

13. Chabi A, Varma R, Tsai JC, et al. Randomized clinical trial of the efficacy and safety of preservative-free tafluprost and timolol in patients with open-angle glaucoma or ocular hypertension. Am J Ophthalmol. 2012; 153(6):1187-1196.

14. Baudouin C. Side effects of antiglaucomatous drugs on the ocular surface. Curr Opin Ophthalmol. 1996;7(2):80-86.

15. Vaede D, Baudouin C, Warnet JM, Brignole-Baudouin F. Preservatives in eye drops: toward awareness of their toxicity. J Fr Ophthalmol. 2010; 33(7):505-524. French.

16. Brasnu E, Brignole-Baudouin F, Riancho L, Guenoun JM, Warnet JM, Baudouin C. In vitro effects of preservative-free tafluprost and preserved latanoprost, travoprost, and bimatoprost in a conjunctival epithelial cell line. Curr Eye Res. 2008;33(4):303-312.

17. Liang H, Baudouin C, Pauly A, Brignole-Baudouin F. Conjunctival and corneal reactions in rabbits following short- and repeated exposure to preservative-free tafluprost, commercially available latanoprost and $0.02 \%$ benzalkonium chloride. $\mathrm{Br}$ J Ophthalmol. 2008; 92(9):1275-1282.

18. Kahook MY, Noecker R. Quantitative analysis of conjunctival goblet cells after chronic application of topical drops. Adv Ther. 2008; 25(8):743-751.

19. Jaenen N, Baudouin C, Pouliquen P, Manni G, Figueiredo A, Zeyen T. Ocular symptoms and signs with preserved and preservative-free glaucoma medications. Eur J Ophthalmol. 2007;17(3):341-349.

20. Pisella PJ, Pouliquen P, Baudouin C. Prevalence of ocular symptoms and signs with preserved and preservative free glaucoma medication. Br J Ophthalmol. 2002;86(4):418-423.

21. Nordmann JP, Auzanneau N, Ricard S, Berdeaux G. Vision related quality of life and topical glaucoma treatment side effects. Health Qual Life Outcomes. 2003;1:75.

22. Zimmerman TJ, Hahn SR, Gelb L, Tan H, Kim EE. The impact of ocular adverse effects in patients treated with topical prostaglandin analogs: changes in prescription patterns and patient persistence. J Ocul Pharmacol Ther. 2009;25(2):145-152.

23. Arias A, Schargel K, Ussa F, Canut MI, Robles AY, Sánchez BM. Patient persistence with first-line antiglaucomatous monotherapy. Clin Ophthalmol. 2010;4:261-267.

24. Leung EW, Medeiros FA, Weinreb RN. Prevalence of ocular surface disease in glaucoma patients. J Glaucoma. 2008;17(5):350-355.

25. Erb C, Gast U, Schremmer D. German register for glaucoma patients with dry eye. I. Basic outcome with respect to dry eye. Graefes Arch Clin Exp Ophthalmol. 2008;246(11):1593-1601.

26. Baudouin C, Renard JP, Nordmann JP, et al. Prevalence and risk factors for ocular surface disease among patients treated over the long term for glaucoma or ocular hypertension. Eur J Ophthalmol. Epub June 11, 2012.

27. Lawin MJ, Wormald RP, Migdal CS, Hitchings RA. The influence of prior therapy on the success of trabeculectomy. Arch Ophthalmol. 1990; 108(11):1543-1548.

28. Santen Oy. Taflotan ${ }^{\circledR}$ [summary of product characteristics]. Tampere: Santen Oy; 2008.

29. Mizoguchi T, Ozaki M, Unoki K, Dake Y, Eto T, Arai M. A randomized crossover study comparing tafluprost $0.0015 \%$ with travoprost $0.004 \%$ in patients with normal-tension glaucoma [corrected]. Clin Ophthalmol. 2012;6:1579-1584.

30. Ang A, Reddy MA, Shepstone L, Broadway DC. Long term effect of latanoprost on intraocular pressure in normal tension glaucoma. $\mathrm{Br} J$ Ophthalmol. 2004;88(5):630-634.
31. Ang GS, Kersey JP, Shepstone L, Broadway DC. The effect of travoprost on daytime intraocular pressure in normal tension glaucoma: a randomised controlled trial. Br J Ophthalmol. 2008;92(8):1129-1133.

32. Suh MH, Park KH, Kim DM. Effect of travoprost on intraocular pressure during 12 months of treatment for normal-tension glaucoma. Jpn J Ophthalmol. 2009;53(1):18-23.

33. Tsumura T, Yoshikawa K, Suzumura H, et al. Bimatoprost ophthalmic solution $0.03 \%$ lowered intraocular pressure of normal-tension glaucoma with minimal adverse events. Clin Ophthalmol. 2012;6:1547-1552.

34. Dirks MS, Noecker RJ, Earl M, Roh S, Silverstein SM, Williams RD. A 3-month clinical trial comparing the IOP-lowering efficacy of bimatoprost and latanoprost in patients with normal-tension glaucoma. $A d v$ Ther. 2006;23(3):385-394.

35. Sawada A, Yamamoto T, Takatsuka N. Randomized crossover study of latanoprost and travoprost in eyes with open-angle glaucoma. Graefes Arch Clin Exp Ophthalmol. 2012;250(1):123-129.

36. Nomura Y, Nakakura S, Moriwaki M, Takahashi Y, Shiraki K. Effect of travoprost on 24-hour intraocular pressure in normal tension glaucoma. Clin Ophthalmol. 2010;4:643-647.

37. Konstas AG, Kozobolis VP, Katsimpris IE, et al. Efficacy and safety of latanoprost versus travoprost in exfoliative glaucoma patients. Ophthalmology. 2007;114(4):653-657.

38. Konstas AG, Holló G, Irkec M, et al. Diurnal IOP control with bimatoprost versus latanoprost in exfoliative glaucoma: a crossover, observermasked, three-centre study. Br J Ophthalmol. 2007;91(6):757-760.

39. Johnson TV, Fan S, Camras CB, Toris CB. Aqueous humor dynamics in exfoliation syndrome. Arch Ophthalmol. 2008;126(7):914-920.

40. Hedman K, Alm A. A pooled-data analysis of three randomized, double-masked, six-month clinical studies comparing the intraocular pressure reducing effect of latanoprost and timolol. Eur J Ophthalmol. 2000;10(2):95-104.

41. Denis P, Baudouin C, Bron A, et al. First-line latanoprost therapy in ocular hypertension or open-angle glaucoma patients: a 3-month efficacy analysis stratified by initial intraocular pressure. BMC Ophthalmol. 2010;10:4

42. Hommer A, Mohammed Ramez O, Burchert M, Kimmich F. IOPlowering efficacy and tolerability of preservative-free tafluprost $0.0015 \%$ among patients with ocular hypertension or glaucoma. Curr Med Res Opin. 2010;26(8):1905-1913.

43. Uusitalo HM, Pillunat LE, Baudouin C, et al. Phase III, 24-month study investigating the efficacy and safety of tafluprost vs latanoprost in patients with open-angle glaucoma or ocular hypertension. Acta Ophthalmol. 2008;86(Suppl):S243.

44. Hamacher T, Airaksinen J, Saarela V, Liinamaa MJ, Richter U, Ropo A. Efficacy and safety levels of preserved and preservative-free tafluprost are equivalent in patients with glaucoma or ocular hypertension: results from a pharmacodynamics analysis. Acta Opthtalmol Suppl (Oxf). 2008;S242:14-19.

45. Uusitalo H, Chen E, Pfeiffer N, et al. Switching from a preserved to a preservative-free prostaglandin preparation in topical glaucoma medication. Acta Ophthalmol. 2010;88(3):329-336.

46. Janulevičienè I, Derkač I, Grybauskiene L, Paulauskaitė R, Gromnickaite R, Kuzmienė L. Effects of preservative-free tafluprost on tear film osmolarity, tolerability, and intraocular pressure in previously treated patients with open-angle glaucoma. Clin Ophthalmol. 2012;6: 103-109.

47. Faridi UA, Saleh TA, Ewings P, et al. Comparative study of three prostaglandin analogues in the treatment of newly diagnosed cases of ocular hypertension, open-angle and normal tension glaucoma. Clin Experiment Ophthalmol. 2010;38(7):678-682. 


\section{Publish your work in this journal}

Clinical Ophthalmology is an international, peer-reviewed journal covering all subspecialties within ophthalmology. Key topics include: Optometry; Visual science; Pharmacology and drug therapy in eye diseases; Basic Sciences; Primary and Secondary eye care; Patient Safety and Quality of Care Improvements. This journal is indexed on

Submit your manuscript here: http://www.dovepress.com/clinical-ophthalmology-journal
PubMed Central and CAS, and is the official journal of The Society of Clinical Ophthalmology (SCO). The manuscript management system is completely online and includes a very quick and fair peer-review system, which is all easy to use. Visit http://www.dovepress.com/ testimonials.php to read real quotes from published authors. 